\title{
DIFFERENCES IN MOTIVATION OF HEALTH CARE PROFESSIONALS IN PUBLIC AND PRIVATE HEALTH CARE CENTERS
}

\author{
Lepa Babićc ${ }^{1, *}$, Boris Kordić2 ${ }^{\text {, Jovana Babić }}{ }^{3}$ \\ ${ }^{1}$ Singidunum University, Faculty of Business \\ 32 Danijelova Street, Belgrade, Serbia \\ ${ }^{2}$ Faculty of Security Studies, University of Belgrade \\ Gospodara Vučića 50, Belgrade, Serbia \\ ${ }^{3}$ Faculty of Philosophy, Department of Psychology, University of Belgrade, MA student \\ Čika Ljubina 18-20, Belgrade, Serbia
}

\begin{abstract}
:
It is very important to achieve client satisfaction in the health care sector, which is why the issue of motivation of health care professionals is always an interesting topic to explore. Having in mind the current situation in the private health care sector in Serbia, we have decided to examine the differences in satisfaction of motivational needs in health care professionals, with an emphasis on differences between health care professionals working in public and private health care centres. We have used Maslow and Herzberg's motivation theories when designing the appropriate questionnaire. The results obtained have revealed differences between subsamples. Health care professionals working in the private sector are more satisfied with their salaries, working conditions, job certainty and opportunities for professional development.
\end{abstract}

\section{Key words:}

Maslow's hierarchy of needs theory, Herzberg's two-factor theory, health care professionals.

\section{INTRODUCTION}

All activities of a company are realized through performance of its employees (Zámečník, 2014, p. 851). Employee motivation and engagement have always been the most interesting segments of research (Sanyal and Biswas, 2014, p. 185), although some believe that the topic of motivation has seen little empirical or theoretical research over the last fifteen years (Zámečník, 2014, p. 851). Employees conduct their activities diligently when driven by goals and incentives they find valuable (Robbins and Coulter, 2007). Work motivation is an extremely relevant factor which affects the quality and content of work-related outcomes in health care sector (Toode et al., 2011, p. 246). The workforce in this sector has specific features that cannot be ignored and health organizations are faced with external pressures that cannot be effectively met without appropriate workforce adjustments (Dussault and Dubois, 2003). In order to use human resources most effectively, health care organizations must assume a more systemic approach - one that accounts for factors beyond narrowly defined human resources management practices and includes organizational and institutional conditions (Dubois and Singh, 2009). 
Work motivation is especially worth considering if we have in mind that dissatisfied doctors are a worldwide phenomenon (Edwards et al., 2002). The health system in many countries suffers due to the years of non-investment, which has resulted in poor salaries for health care professionals, poor working conditions, absence of leadership and many other incentives (Stilwell et al., 2004; Martinez et al., 2009). Domestic research results indicate that the strongest dissatisfaction in health care workers is associated with their salary and reward system (Čizmić and Milanović, 2004). Research conducted in China and Tanzania showed that the most important factors for performance improvement of health care professionals are the opportunities for professional development, opportunities for training and skill improvement, working environment, raises, working conditions and salaries (Hung et al., 2013; Manongi et al., 2006). Health professionals in Slovenia and Croatia have stated that their suggestions and eagerness for professional development are not taken into consideration when implementing changes in health care centers (Skela Savič and Pagon, 2008; Skela Savič and Robida, 2013). Almost two-thirds of medical staff in Australia has thought about leaving the public sector (Dalton, 2010). Having this in mind, we have decided to explore differences in motivation of health care professionals employed in public and private health care centers in Belgrade, Serbia.

Out of numerous motivation theories, we have choosen the following two for the purpose of this paper: the hierarchy of needs theory developed by Abraham Maslow (Maslow, 1943) and the two-factor theory developed by Frederick Herzberg (Herzberg, 1964). Maslow's theory has been adapted successfully to the healthcare area (Benson and Dundis, 2003; Herbst, 2006; Zalenski and Raspa, 2006; Duncan and Blugis, 2011). Herzberg's theory has been used as a method to explore employee job satisfaction (Matzle and Renzl, 2007; Smerek and Peterson, 2007; Lundberg et al., 2009). There are also researchers who use both theories (Ticu, 2013).

The hierarchy of the needs theory states that human needs could be ranked starting from the physiological needs, i.e. bodily needs, to those related to self-development, which means to become what everybody wants and is able to become (Maslow, 1942). In between are safety needs, the social needs (friendship, acceptance) and assessment needs (selfesteem, recognition). The theory posits that certain needs take precedence over the others. Once the most fundamental needs have been largely satisfied, safety needs are those that guide individual's actions. After that, needs for love, affection, and belonging become the most important. Afterwards, individuals attempt to satisfy self-esteem and they eventually strive for self-actualization.

The two-factor theory proposes that the relationship between the actors and their work is such that the different elements of the work situation satisfy or dissatisfy two different sets of needs. Hygiene factors are related to the working environment and include company policy and administration, supervision, relationship with supervisor, work conditions, salary, relationships with peers, personal life, and relationships with subordinates, status, and security. These factors can cause dissatisfaction when not gratified. However, when gratified these factors do not cause satisfaction. Motivating factors are intrinsic within the work itself and include achievement, recognition, work itself, responsibility, advancement, and growth. Herzberg proposed that the presence of hygiene factors leads to baseline satisfaction, but motivators are necessary to generate greater employee commitment and performance. These factors when fulfilled cause satisfaction, and when absent they do not cause dissatisfaction (Herzberg, 1971).

\section{PROBLEM}

In order to explore how differences between private and public health care centres in Belgrade affect satisfaction and/or dissatisfaction of needs of health care professionals, the detailed survey has been conduced, as elaborated in the text below.

\section{METHOD}

\section{Survey instrument}

The questionnaire used to measure motivation of health care professionals was constructed for the purposes of this research. Prior to questions on motivation, there is a set of questions collecting demographic data concerning gender, age, education, position and working experience. Further statements in the questionnaire are derived from motivation theories of Maslow and Herzberg. The first part of the questionnaire consists of 21 items based on Maslow's hierarchy of needs theory and the second part including 13 items refers to Herzberg's theory of two factors and consists of a scale measuring motivators and a scale measuring hygiene factors. The answers are measured by a 5 -point Likert scale. 


\section{Participants and data collection}

The survey included public and private health care centres in Belgrade. The data were obtained by questioning 100 health care professionals. There were 15 men and 85 women aged 20 to 66 whose working experience ranges from 4 months to 39 years. The survey comprised 43 respondents in the nursing profession and 57 doctors.

In a subsample of health care professionals working in public health care centres, there were 57 respondents, including 7 men and 50 women aged 24 to 63 whose working experience ranged from 5 months to 35 years. Out of the total number of respondents, 23 of them were in the nursing profession and 34 were doctors.

In a subsample of health care professionals working in private health care centres there were 43 respondents, including 8 men and 35 women aged 20 to 66 whose working experience ranged from 4 moths to 39 years. Out of the total number of respondents within this subsample, 20 of them were in the nursing profession and 23 were doctors.

\section{RESULTS}

The results obtained on 21 items derived from Maslow's theory were submitted to the factor analysis. Five factors were preserved for the decision about the number of relevant factors. Factors were promax rotated with Kaiser Normalization. They cover $76.444 \%$ of variance (5 factors explain $41.09 \%$, $15.05 \%, 8.21 \%, 7.08 \%, 5.02 \%$ of variance respectively). Cronbach's alpha for the entire scale is 0.908 . These are the factors:

\begin{tabular}{lc} 
I am satisfied with the salary I receive & 0.866 \\
\hline $\begin{array}{l}\text { Bonus (stimulation) plan in the company is } \\
\text { satisfying }\end{array}$ & 0.857 \\
\hline $\begin{array}{l}\text { There are reasonable periodic increases } \\
\text { My salary matches my commitment to }\end{array}$ & 0.696 \\
\multicolumn{2}{l}{ work }
\end{tabular}

Table 1. Factor "Existence"

This factor integrates items concerning the satisfaction with salaries, bonuses and raises.
I am satisfied with my working conditions

0.481

I feel I have a job security

0.831

The company implements appropriate

safety precautions

0.890

I am satisfied with the social and pension

insurance

0.697

/values on the right represent the factor loadings/

Table 2. Factor "Safety"

The second factor indicates the evaluation of working conditions, safety precautions and employment stability.

My colleagues and I have a good relationship

0.942

One can feel the presence of co-operation in the company

0.995

My colleagues support me

/values on the right represent the factor loadings/

Table 3. Factor "Sociability"

The third factor indicates the relationship among colleagues at work. It includes co-operation, friendship and mutual support among colleagues.

\begin{tabular}{ll}
\hline $\begin{array}{l}\text { I always get acknowledgment from my su- } \\
\text { periors for a well-performed assignments }\end{array}$ & 0.664 \\
\hline $\begin{array}{l}\text { I can freely express my disagreement with } \\
\text { superiors }\end{array}$ & 0.941 \\
\hline $\begin{array}{l}\text { My colleagues appreciate my contributions } \\
\text { M }\end{array}$ & 0.543
\end{tabular}

/values on the right represent the factor loadings/ Table 4. Factor "Respect"

The fourth factor indicates that employee receives feedback from relationship with supervisors and colleges full of acknowledgment and appreciation.

\begin{tabular}{lc}
\hline $\begin{array}{l}\text { I constantly learn new things at my work- } \\
\text { place }\end{array}$ & 0.714 \\
\hline $\begin{array}{l}\text { My job is challenging and encourages } \\
\text { creativity }\end{array}$ & 1.031 \\
\hline $\begin{array}{l}\text { My job enables me to develop my personal } \\
\text { and professional potentials }\end{array}$ & 0.549 \\
\hline
\end{tabular}

/values on the right represent the factor loadings/ Table 5. Factor "Self-actualisation" 
The fifth factor integrates evaluation of possibilities to acquire knowledge, be creative and develop personal and professional potentials.

Data obtained on items derived from Herzberg's theory were submitted to the factor analysis. Two factors were preserved according to the use of scree criteria for the decision about number of relevant factors. Factors were promax rotated with Kaiser Normalization. They cover $58.805 \%$ of variance (2 factors explain $38.63 \%$ and $20.18 \%$ of variance respectively). Cronbach's alpha for the scales based on Herzberg's theory is 0.875 for motivators and 0.759 for hygiene scale. These are the factors:

To which extent is your job satisfaction affected by:

\begin{tabular}{|c|c|}
\hline your success with what you do & 0.768 \\
\hline the responsibilities you have at work & 0.568 \\
\hline possibilities of knowledge advancements & 0.842 \\
\hline advancement in the organization & 0.830 \\
\hline $\begin{array}{l}\text { your supervisors' acknowledgment for the } \\
\text { results you achieve }\end{array}$ & 0.825 \\
\hline $\begin{array}{l}\text { your colleagues' acknowledgment for the } \\
\text { results you achieve }\end{array}$ & 0.836 \\
\hline
\end{tabular}

/values on the right represent the factor loadings/ Table 6. Factor "Motivators"

This factor covers evaluations of the extent to which job satisfaction is affected by success, responsibilities, possible advancements and acknowledgment.

To which extent is your job dissatisfaction affected by:

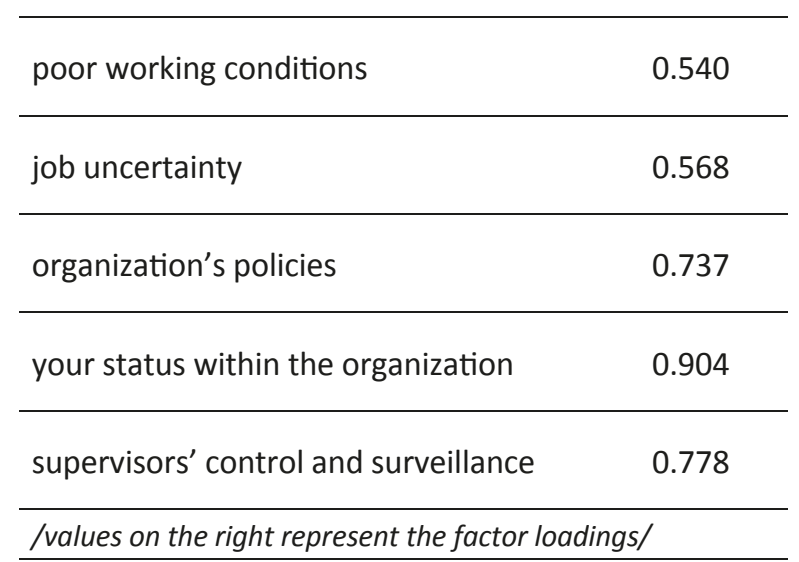
Table 7. Factor "Hygiene"
The second factor includes items concerning organization policies, control and surveillance and one's position within the company and it indicates the characteristics of the work place.

\begin{tabular}{lcc}
\hline Variable & AS & SD \\
\hline sociability & 3.63 & 0.84 \\
\hline motivators & 3.54 & 0.99 \\
\hline self-actualization & 3.39 & 1.01 \\
\hline safety & 3.31 & 0.95 \\
\hline respect & 2.96 & 0.90 \\
\hline hygiene & 2.47 & 0.89 \\
\hline existence & 2.18 & 1.08 \\
\hline
\end{tabular}

Table 8. Arithmetic means and standard deviations sorted from most to least satisfied

It can be noted that respondents perceive their social need as most satisfied, followed by motivators and self-actualization, and their existential needs as least satisfied.

The hygiene factor correlates with only two other factors. It has a positive correlation with sociability and a negative correlation with motivators.

\section{Differences between public and private health centres}

The comparative results of the average values of all 7 factors of motivation are shown in Table 10. T-test (independent samples test) was used for the comparison of two samples of health care professionals (working in public and private health care centres).

It can be noted that two groups differ significantly in three factors: existence, safety and selfactualisation. 


\begin{tabular}{|c|c|c|c|c|c|c|c|c|}
\hline & safety & \multicolumn{2}{|c|}{ sociability } & respect & $\begin{array}{c}\text { self- } \\
\text { actualization }\end{array}$ & \multicolumn{2}{|c|}{ motivators } & hygiene \\
\hline existence & $0.534 * *$ & \multicolumn{2}{|c|}{$0.197^{*}$} & $0.411 * *$ & $0.467^{* *}$ & \multicolumn{2}{|c|}{$0.389 * *$} & 0.003 \\
\hline safety & 1.000 & \multicolumn{2}{|c|}{$0.431^{* *}$} & $0.482^{* *}$ & $0.493 * *$ & \multicolumn{2}{|c|}{$0.430 * *$} & 0.075 \\
\hline sociability & & \multicolumn{2}{|c|}{1.000} & $0.607^{* *}$ & $0.526 * *$ & \multicolumn{2}{|c|}{$0.244^{*}$} & $0,232 *$ \\
\hline respect & & & & 1.000 & $0.526 * *$ & \multicolumn{2}{|c|}{$0.431^{* *}$} & 0.141 \\
\hline self-actualization & & & & & 1.000 & \multicolumn{2}{|c|}{$0.422 * *$} & 0.076 \\
\hline motivators & & & & & & \multicolumn{2}{|c|}{1.000} & $-0.290 * *$ \\
\hline \multicolumn{9}{|c|}{$\begin{array}{l}\text { Extraction Method: Principal Component Analysis. Rotation Method: Promax with Kaiser Normalization. } \\
\text { **-correlation is significant at the } .01 \text { level (2-tailed). } \\
\text { *_correlation is significant at the } .05 \text { level (2-tailed). } \\
\text { Table 9. Inter-correlations of principal components }\end{array}$} \\
\hline \multirow[t]{3}{*}{ HEALTH CARE CENTER } & & & AS & SD & $\mathrm{F}$ & df1 & df2 & Sig. \\
\hline & & & 1.71 & 0.92 & 0.104 & 98 & 89.121 & 0,000 \\
\hline & & & 3.02 & 0.91 & 0.492 & 98 & 91.963 & 0,000 \\
\hline \multirow{7}{*}{$\begin{array}{l}\text { PUBLIC } \\
N=57\end{array}$} & & & 3.55 & 0.81 & 0.138 & 98 & 86.598 & 0,271 \\
\hline & & & 2.93 & 0.91 & 0.334 & 98 & 91.559 & 0,732 \\
\hline & self-ac & ation & 3.18 & 1.07 & 3.396 & 98 & 97.533 & 0,012 \\
\hline & & & 3.38 & 1.05 & 3.906 & 98 & 97.326 & 0,062 \\
\hline & & & 2.42 & 0.87 & 0.015 & 98 & 88.011 & 0,593 \\
\hline & & & 2.81 & 0.95 & & & & \\
\hline & & & 3.69 & 0.88 & & & & \\
\hline \multirow[t]{5}{*}{$\begin{array}{l}\text { PRIVATE } \\
N=43\end{array}$} & & & 3.74 & 0.87 & & & & \\
\hline & & & 2.99 & 0.88 & & & & \\
\hline & self-ac & ation & 3.68 & 0.86 & & & & \\
\hline & & & 3.76 & 0.86 & & & & \\
\hline & & & 2,52 & 0,92 & & & & \\
\hline
\end{tabular}

Table 10. Arithmetic means, standard deviations and F-test of significance of differences between arithmetic means for 7 factor between the health care professionals working in public and private health care centers 


\begin{tabular}{lc}
\hline Factors & Function \\
\hline existence & 0.822 \\
\hline safety & 0.510 \\
\hline self-actualization & 0.356 \\
\hline motivators & 0.264 \\
\hline sociability & 0.155 \\
\hline hygiene & 0.075 \\
\hline respect & 0.048 \\
\hline
\end{tabular}

Table 11. Structure matrix of canonical discriminative function

Coefficient of canonical correlation as the index of maximal differentiations of health care professionals working in public and private health care centres on linear function composed of scores of the given 7 factors extracted in our research is 0.586 (Wilks Lambda $=.657$, Chi-square $=39.737, \mathrm{df}=7, \mathrm{p}$ $<.001)$. Table 10. shows that the discriminative function which maximally differentiates professionals working in public from professionals working in private health care centres is mostly determined by "existence", and then by "safety". Group centroids on this function are: public -0.622 , and private 0.824 . These results point to the fact that the needs of those working in private health care centres are more satisfied in existence, safety and self-actualization.

It is worth noting that there were no significant differences between doctors and nurses and no differences in terms of working experience and other demographic variables.

\section{DISCUSSION}

First, we will discuss factors derived from Maslow's theory. Factor Existence coincides with satisfaction of basic needs in Maslow's hierarchy simply because nowadays money can provide the means to satisfy those needs. In the general sample, these are the needs estimated as least satisfied, meaning that salaries are perceived as low and are not matching the commitment to work. This can be related to the poor economic situation not only in Serbia but in the entire region.
Factor Safety is important for an employee to feel safe and protected in his working environment in order to do his best, especially in professions such as health care. Working as a health care professional provides employment certainty, because the chances of dismissal are rather low. Working conditions in the public sector are not as satisfying as those in the private health care sector. Therefore, this need is more satisfied among health care professionals working in private health care centres.

The Sociability factor is most satisfied in our sample of health care professionals compared to other needs and motivators/hygiene factors examined (Table 9). This means that horizontal communication, namely communication between colleagues of the same status and profession is being friendly and supportive. Sociability has statistically significant positive correlations with all other factors, but the correlation with Motivators is rather low. We could say that employees enjoy communicating with their co-workers, but this kind of communication and satisfaction is not what makes them motivated to do their job.

On the other hand, the Respect factor has been estimated as quite poor. It analyses concerns the relationship health care professionals have with their supervisors. Perceived lack of positive feedback in communication and respect for one's opinion could be understood as a deficit in mutual professional communication with supervisors. These results are in contrast with high satisfied sociability needs and self-actualization needs, but they coincide with the results from health care professionals surveyed in Slovenia and Croatia (Skela Savič and Pagon, 2008, Skela Savič and Robida, 2013). Vertical communication is influenced by professionals' values and the existence of appropriate institutional coordination mechanisms (Martinez et al., 2009). This means that although horizontal communication within health care centers is good, vertical communication requires improvement. Even though these types of improvements can be complicated, they are necessary for the overall improvement of the system. Further research could be focused on examining feedback professionals get from their supervisors and whether it contains acknowledgment for their work.

The Self-actualization factor is assessed in the general sample as the third most satisfied, preceded by Sociability and Motivators. In accordance with other research (Hung et al., 2013), opportunities for professional development, training and skill improvement are some of the most important work in- 
centives. The nature of their job allows health care professionals to observe every new case as an opportunity to learn, find alternative solutions to similar problems and improve themselves in multiple ways. There is also a need to continuously work on knowledge improvement due to new findings in medicine and pharmacotherapy. Very often health care workers have seminars on such discoveries.

The factor Motivators, based on Herzberg's theory, covers evaluations of the extent to which job satisfaction is affected by success, responsibilities, possible advancements and acknowledgment. Successful interventions toward patients, acquiring new knowledge and making advancements are the most important subjects affecting job satisfaction of health care professionals. Noteworthy is the fact that factor Motivators from Herberg theory correlates significantly on .001 level with all factors of Maslow's theory except with Sociability. This means that Sociability is an important need to be satisfied but not as important to be one of the leading motivators which stimulate employee committment to work.

The Hygiene factor is the only factor measuring dissatisfaction. If the rules are not clear, procedures not followed and communication inadequate, employees will be dissatisfied because it is unclear how they should behave in certain situations. The Hygiene factor shows moderate dissatisfaction in our sample. Negative correlation with Motivators means that in our sample health care workers are demotivated with hygiene factors. This is in tune with the fact that Hygiene correlates only with Sociability, among of all factors from Maslow's theory. We have already identified lower correlation between Sociability and Motivators, and now we can add that Sociability could be seen as an important factor for lowering dissatisfaction at work place. Origins of these correlations should be further investigated taking into consideration the nature and specificity of this profession.

Our research confirms the existence of differences in satisfaction of needs between health care professionals working in private and public health care centres (see Table 10). Such differences are present in three factors: Existence, Safety and Self-actualisation. It should also be mentioned that we have encountered differences when using the theory of hierarchy of needs and not the two-factor theory. Employees in private health care centres are more satisfied with their salaries, bonuses and increases, as well as with with their working conditions and opportunities for further personal and professional development.
These results raise various questions that need to be answered in further research. Are the salaries in private health centres really significantly higher and are their budgets distributed in a more appropriate way considering the profession? Are the working conditions really better in the private sector and which are the segments that differentiate the conditions in private health care centres from those in the public sector? Are educations and seminars more frequent and better organised in the private sector? It would also be interesting to examine the fluctuation among public and private sectors. Are employees in the public sector attracted to transfer into the private health care centres due to greater privileges? What are the factors preventing them to make such a step?

Our research shows that exploring the differences between public and private sector is worth it, but that it is desireable to use different approaches i.e., theories, in order to get valid and usable results.

\section{CONCLUSION}

Maslow's theory of hierarchy of needs has revealed significant diffrences between health care professionals working in public and private health care centres. On the other hand, the use of twofactor theory has not led to any such findings. The needs of health care workers in the private sector are more satisfied when it comes to existence, safety and self-actualisation. The results obtained can be used for gaining a more clear perception of the situation in the labour market in the health care sector, as well as for further improvement of working conditions in public health care centres.

\section{REFERENCES}

Benson, S.G., \& Dundis, S.P. (2003). Understanding and motivating health care employees: integrating Maslow's hierarchy of needs, training and technology. Journal of Nursing Management, 11(5), 315-320.

Čizmić, S.M., \& Milanović, S.S. (2004). Work motivation of employees exposed to ionizing radiation. Bilten Instituta za nuklearne nauke Vinča, 9(1-4), 23-31.

Dalton, S. (2010). Motivating medicine: Why money is not enough. Journal of Paediatrics and Child Health, 46(4), 142-143.

Dubois, C., \& Singh, D. (2009). From staff-mix to skill-mix and beyond: towards a systemic approach to health workforce management. Human Resources for Health, 7(87), 1-19. DOI:10.1186/1478-4491-7-87. 
Duncan, M.K.W., \& Blugis, A. (2011). Maslow's Needs Hierarchy as a Framework for Evaluating Hospitality Houses' Resources and Services. Journal of Pediatric Nursing, 26(4), 325-331. DOI: 10.1016/j. pedn.2010.04.003.

Dussault, G., \& Dubois, C. (2003). Human resources for health policies: A critical component in health policies. Human resources for health, 1(1), 1-16. DOI: 10.1186/1478-4491-1-1.

Edwards, N., Nomacki, M., \& Silversin, J. (2002). Unhappy doctors: what are the causes and what can be done. British Medical Journal, 324, 835-838. DOI:10.1136/ bmj.324.7341.835.

Herbst, L.H. (2006). Applying the concepts from Maslow in a large U.S. hospice program. Journal of Palliative Care, 9(5), 1049-1050. DOI:10.1089/jpm.2006.9.104.

Herzberg, F. (1964). The Motivation-Hygiene Concept and Problems of Manpower. Personnel Administrator, 27(1), 3-7.

Herzberg, F. (1971). Work and the nature of man. New York: World Publishing.

Hung, L.M., Shi, L., Wang, H., Nie, X., \& Mengm Q. (2013). Chinese primary care providers and motivating factors on performance. Family Practice, 30(5), 576-586.

Lundberg, C., Gudmundson, A., \& Andersson, T. D. (2009). Herzberg's Two-Factor Theory of work motivation tested empirically on seasonal workers in hospitality and tourism. Tourism Management, 30(6), 890-899.

Manongi, R.N., Marchant, T.C., \& Bygbjerg, I.C. (2006). Improving motivation among primary health care workers in Tanzania: a health worker perspective. Human resources for health, 4(6). DOI: 10.1186/14784491-4-6.

Martínez, D.H., Vásquez Navarrete, M.L., \& Vagras Lorenzo, I. (2009). Factors influencing coordination among healthcare levels according to the opinion of healthcare managers and health professionals. Gaceta sanitaria, 23(4), 280-286. DOI:10.1016/j.gaceta.2008.05.001.

Maslow, A.H. (1943). A Theory of Human Motivation. Psychological Review, 50(4), 370-396.

Matzle, K., \& Renzl, B. (2007). Assessing asymmetric effects in the formation of employee satisfaction. Tourism Management, 28(4), 1093-1103. DOI: 10.1016/j. tourman.2006.07.009.
Robbins, S.P., \& Coulter, M.K. (2007). Management. New Jersey: Prentice Hall.

Sanyal, M.K., \& Biswas, S.B. (2014). Employee motivation from performance appraisal implications: Test of a theory in the software industry in West Bengal (India). Procedia Economics and Finance, 11, 182-196. DOI: 10.1016/S2212-5671(14)00187-7.

Skela Savič, B., \& Pagon, M. (2008). Individual involvement in health care organizations: differences between professional groups, leaders and employees. Stress Health, 24, 71-84. DOI: 10.1002/smi.1164.

Skela Savič, B., \& Robida, A. (2013). Capacity of middle management in health-care organizations for working with people - the case of Slovenian hospitals. Human Resources for Health, 11(18). DOI: 10.1186/1478-449111-18.

Smerek, R.E., \& Peterson, M. (2007). Examining Herzberg's theory: Improving job satisfaction among non-academic employees at a University. Research in Higher Education, 48(2), 229-250. DOI: 10.1007/s11162-0069042-3.

Stilwell, B., Diallo, K., Zurn, P., Vujičić, M., Adams, O., \& Dal Poz, M. (2004). Migration of health-care workers from developing countries: Strategic approaches to its management. Bulletin of the World Health Orgaization, 82, 595-600.

Țicu, D. (2013). Theories of motivation in public policies process. Procedia - Social and Behavioral Sciences, 92, 925-929. DOI: 10.1016/j.sbspro.2013.08.778.

Toode, K., Routasalo, P., \& Suominen, T. (2011). Work motivation of nurses: A literature review. International Journal of Nursing Studies, 48(3), 246-257. DOI: 10.1016/j.ijnurstu.2010.09.013.

Zalenski, R. J., \& Raspa, R. (2006). Maslow's Hierarchy of Needs: A framework for achieving human potential in hospice. Journal of Palliative Medicine, 9(5), 11201127.

Zámečník, R. (2014). The measurement of employee motivation by using multi-factor statistical analysis. Procedia - Social and Behavioral Sciences, 109, 851-857. DOI: 10.1016/j.sbspro.2013.12.553. 


\section{RAZLIKE U MOTIVACIJI ZAPOSLENIH}

\section{U DRŽAVNIM I PRIVATNIM DOMOVIMA ZDRAVLJA}

\section{Rezime:}

U zdravstvenom sektoru je izuzetno važno postići zadovoljstvo klijenata i stoga je pitanje motivacije zaposlenih u tom sektoru uvek interesantno za istraživanje. S obzirom na razvoj privatnog sektora zdravstva u Srbiji odlučili smo da ispitamo razlike u zadovoljenju motivacionih potreba zaposlenih u zdravstvenom sektoru, s posebnim osvrtom na razliku između privatnog i državnog sektora. $U$ konstruisanju istraživačkog upitnika pošli smo od motivacionih teorija Maslova i Hercberga. Rezultati su pokazali da postoje razlike među poduzorcima. Zdravstveni radnici u privatnom sektoru su zadovoljniji platom, radnim uslovima, sigurnošću posla i mogućnostima za profesionalni razvoj.

\section{Ključne reči:}

Maslovljeva teorija hijerarhije potreba,

Hercbergova dvofaktorska teorija,

zdravstveni radnici.

Received: October 5th, 2014.

Correction: October 17th, 2014.

Accepted: October 22nd, 2014. 